\title{
Front Matter: Volume 9122
}

, "Front Matter: Volume 9122," Proc. SPIE 9122, Next-Generation Analyst II, 912201 (10 June 2014); doi: 10.1117/12.2072300

SPIE Event: SPIE Sensing Technology + Applications, 2014, Baltimore, MD, United SPIE. States 


\title{
PROCEEDINGS OF SPIE
}

\section{Next-Generation Analyst II}

\author{
Barbara D. Broome \\ David L. Hall \\ James Llinas \\ Editors
}

6 May 2014

Baltimore, Maryland, United States

Sponsored and Published by

SPIE 
The papers included in this volume were part of the technical conference cited on the cover and title page. Papers were selected and subject to review by the editors and conference program committee. Some conference presentations may not be available for publication. The papers published in these proceedings reflect the work and thoughts of the authors and are published herein as submitted. The publisher is not responsible for the validity of the information or for any outcomes resulting from reliance thereon.

Please use the following format to cite material from this book:

Author(s), "Title of Paper," in Next-Generation Analyst II, edited by Barbara D. Broome, David L. Hall, James Llinas, Proceedings of SPIE Vol. 9122 (SPIE, Bellingham, WA, 2014) Article CID Number.

ISSN: 0277-786X

ISBN: 9781628410594

Published by

SPIE

P.O. Box 10, Bellingham, Washington 98227-0010 USA

Telephone +1 3606763290 (Pacific Time) · Fax +1 3606471445

SPIE.org

Copyright (C) 2014, Society of Photo-Optical Instrumentation Engineers.

Copying of material in this book for internal or personal use, or for the internal or personal use of specific clients, beyond the fair use provisions granted by the U.S. Copyright Law is authorized by SPIE subject to payment of copying fees. The Transactional Reporting Service base fee for this volume is $\$ 18.00$ per article (or portion thereof), which should be paid directly to the Copyright Clearance Center (CCC), 222 Rosewood Drive, Danvers, MA 01923. Payment may also be made electronically through CCC Online at copyright.com. Other copying for republication, resale, advertising or promotion, or any form of systematic or multiple reproduction of any material in this book is prohibited except with permission in writing from the publisher. The CCC fee code is 0277-786X/14/\$18.00.

Printed in the United States of America.

Publication of record for individual papers is online in the SPIE Digital Library.

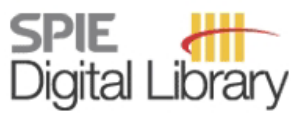

SPIEDigitalLibrary.org

Paper Numbering: Proceedings of SPIE follow an e-First publication model, with papers published first online and then in print and on CD-ROM. Papers are published as they are submitted and meet publication criteria. A unique, consistent, permanent citation identifier (CID) number is assigned to each article at the time of the first publication. Utilization of CIDs allows articles to be fully citable as soon as they are published online, and connects the same identifier to all online, print, and electronic versions of the publication. SPIE uses a six-digit CID article numbering system in which:

- The first four digits correspond to the SPIE volume number.

- The last two digits indicate publication order within the volume using a Base 36 numbering

system employing both numerals and letters. These two-number sets start with 00, 01, 02, 03, 04, $05,06,07,08,09,0 A, 0 B \ldots 0 Z$, followed by 10-1Z, 20-2Z, etc.

The CID Number appears on each page of the manuscript. The complete citation is used on the first page, and an abbreviated version on subsequent pages. Numbers in the index correspond to the last two digits of the six-digit CID Number. 


\title{
Contents
}

\author{
$\checkmark \quad$ Conference Committee \\ vii Introduction
}

\section{SESSION 1 INFORMATION FUSION AND ANALYSIS}

912202 Automatic theory generation from analyst text files using coherence networks [9122-1]

S. C. Shaffer, The Pennsylvania State Univ. (United States)

912203 Using Complex Event Processing (CEP) and vocal synthesis techniques to improve comprehension of sonified human-centric data [9122-2]

J. Rimland, M. Ballora, The Pennsylvania State Univ. (United States)

912204 A data fusion approach to indications and warnings of terrorist attacks [9122-3]

D. McDaniel, G. Schaefer, Silver Bullet Solutions, Inc. (United States)

912205 Warfighter information services: lessons learned in the intelligence domain [9122-4]

S. E. Bray, Defence Science and Technology Lab. (United Kingdom)

912206 A survey of automated methods for sensemaking support [9122-5]

J. Llinas, Univ. at Buffalo (United States)

\section{SESSION 2 INFORMATION VISUALIZATION}

912207 Neural network based visualization of collaborations in a citizen science project [9122-6] A. M. M. Morais, R. D. C. Santos, Instituto Nacional de Pesquisas Espaciais (Brazil); M. J. Raddick, Johns Hopkins Univ. (United States)

912208 Visualizing common operating picture of critical infrastructure [9122-7]

L. Rummukainen, L. Oksama, J. Timonen, J. Vankka, National Defence Univ. (Finland)

912209 Visualization of multi-INT fusion data using Java Viewer (JVIEW) [9122-8]

E. Blasch, A. Aved, J. Nagy, S. Scott, Air Force Research Lab. (United States)

$91220 \mathrm{~A}$ A visual analytic framework for data fusion in investigative intelligence [9122-9] G. Cai, The Pennsylvania State Univ. (United States); G. Gross, J. Llinas, Univ. at Buffalo (United States); D. Hall, The Pennsylvania State Univ. (United States)

9122 OB Human terrain exploitation suite: applying visual analytics to open source information [9122-10]

T. Hanratty, J. Richardson, M. Mittrick, J. Dumer, E. Heilman, H. Roy, S. Kase, U.S. Army Research Lab. (United States) 
9122 OC Profile-based autonomous data feeding: an approach to the information retrieval problem in a high communications latency environment [9122-11]

J. Straub, The Univ. of North Dakota (United States)

9122 OD Exploiting social media for Army operations: Syrian crisis use case [9122-12]

S. E. Kase, E. K. Bowman, U.S. Army Research Lab. (United States); M. T. Al Amin,

T. Abdelzaher, Univ. of Illinois at Urbana-Champaign (United States)

$9122 \mathrm{OE} \quad$ A qualitative readiness-requirements assessment model for enterprise big-data infrastructure investment [9122-13]

M. M. Olama, A. W. McNair, S. R. Sukumar, J. J. Nutaro, Oak Ridge National Lab. (United States)

9122 OG Utilizing semantic wiki technology for intelligence analysis at the tactical edge [9122-16]

E. Little, Modus Operandi, Inc. (United States)

\section{SESSION $4 \quad$ PARTICIPATORY SENSING \& COGNITION}

$9122 \mathrm{OH} \quad$ User-centric incentive design for participatory mobile phone sensing [9122-17]

W. Gao, H. Lu, The Univ. of Tennessee Knoxville (United States)

$9122 \mathrm{Ol}$ Conversational sensing [9122-18]

A. Preece, C. Gwilliams, C. Parizas, D. Pizzocaro, Cardiff Univ. (United Kingdom);

J. Z. Bakdash, U.S. Army Research Lab. (United States); D. Braines, IBM United Kingdom Ltd.

(United Kingdom)

$91220 \mathrm{~J} \quad$ Using cognitive architectures to study issues in team cognition in a complex task environment [9122-19]

P. R. Smart, Univ. of Southampton (United Kingdom); K. Sycara, Y. Tang, Carnegie Mellon Univ. (United States)

9122 OK Language and dialect identification in social media analysis [9122-21]

S. Tratz, D. Briesch, U.S. Army Research Lab. (United States); J. Laoudi, ARTI (United States);

C. Voss, V. M. Holland, U.S. Army Research Lab. (United States)

\section{POSTER SESSION}

$9122 \mathrm{OL}$ Application of the JDL data fusion process model to hard/soft information fusion in the condition monitoring of aircraft [9122-22]

J. T. Bernardo, The Pennsylvania State Univ. (United States)

$91220 \mathrm{M} \quad$ Predicting student success using analytics in course learning management systems [9122-23]

M. M. Olama, G. Thakur, A. W. McNair, S. R. Sukumar, Oak Ridge National Lab. (United

States)

Author Index

iv 


\section{Conference Committee}

Symposium Chair

David A. Whelan, Boeing Defense, Space, and Security (United States)

Symposium Co-chair

Wolfgang Schade, Technische Universität Clausthal (Germany) and Fraunhofer Heinrich-Hertz-Institut (Germany)

Conference Chairs

Barbara D. Broome, U.S. Army Research Laboratory (United States)

David L. Hall, The Pennsylvania State University (United States)

James Llinas, University at Buffalo (United States)

Conference Program Committee

Nina M. Berry, Sandia National Laboratories, California (United States)

John S. Eicke, U.S. Army Research Laboratory (United States)

James Fink, U.S. Army Intelligence Center of Excellence

(United States)

Timothy P. Hanratty, U.S. Army Research Laboratory (United States)

James Hendler, Rensselaer Polytechnic Institute (United States)

John E. Lavery, U.S. Army Research Laboratory (United States)

Bob Madahar, Defence Science and Technology Laboratory (United Kingdom)

Paul Sajda, Columbia University (United States)

Alan Steinberg, Georgia Tech Research Institute (United States)

Edward L. Waltz, BAE Systems (United States) 


\section{Introduction}

During the past five years, extensive research has been conducted to develop methods for correlating and fusing data from physical sensors ("hard" data) and from human observers ("soft" data). Hard sensor data generally involves signals, images or scalar information related to the location, identification and characterization of entities, e.g., humans and vehicles, while soft data typically involves textual information, e.g., observations, inferences, and comments, from human observers. Modern Information Fusion systems are also exploiting contextual information, e.g., socio-cultural data, much of which is also of a soft type. With the rapid proliferation of mobile communications devices and increased global connectivity, the need to fuse hard and soft data becomes an increasingly ubiquitous problem. Applications involve areas such as environmental monitoring, citizen science, military situation awareness and assessment, and emergency response. There are numerous challenges involved in hard and soft data fusion based on issues such as: the inherent differences in level of abstraction of hard versus soft data (viz., hard data about observed entities represented by signals, images, vectors and scalars versus semantic meta-data based on human observations and inferences); challenges in characterizing the performance of physical sensors versus human observers; differences in data rates; and issues in correlation and association.

The 2014 SPIE Sensing Technology and Applications Conference included the second annual session on the "Next-Generation Analyst". This conference followed on the model and success of a similarly-themed conference held at SPIE DSS in 2013. The focus this year was on research and advances in hard and soft data fusion. The papers provided an overview and discussion of the state of the art in four sessions: (1) information fusion and analysis, (2) information visualization, (3) big data and information management, and (4) participatory sensing and cognition. Across the four thematic sessions listed, over 20 papers authored by a set of international authors from the USA, the UK, Brazil, and Finland covered top-level research issues toward realizing new capabilities for analysis in very complex environments.

The papers covered a broad range of topics. However, one core theme that emerged was that of the semantic complexities in dealing with language-based data, to include the extensive domain of social media and even data collected by through crowd-sourcing. It was shown for example that for some languages of interest today, even building a capability to recognize a language or dialect of interest can be challenging. Architectural concepts for modern analysis suites included virtual knowledge bases, agent-based approaches, Wiki-based concepts, and user-centric approaches. Visualization ideas and the associated area of human-computer interfacing were also addressed in papers exploring sonification concepts for analyst alerting, multi-functional utilities and visualizations, 
and techniques for maintaining user interest and attention. Among other topics, the concern for input quality, especially in open-source and social-media environments was reflected in many papers, and new frameworks for analysis, such as argumentation-based methods, were also discussed.

Barbara D. Broome David L. Hall James Llinas 